Article

\title{
Perception, motivation and satisfaction of tourist women on their visit to the city of Cordoba (Spain)
}

\author{
Alexandra Lenis Escobar ${ }^{1}$, Ramón Rueda López ${ }^{2 *}$, Manuel Pérez Priego $^{2}$ and María de los Baños \\ García-Moreno García², \\ 1 Researcher at “Grupo de Investigación SEJ-588 Economía del Turismo, de la Cultura y del Deporte. \\ University of Cordoba (UCO)", 14071, Córdoba, Spain; r52leesa@uco.es \\ 2 Department of Statistic, Econometrics, Operational Research, Business Organization and Applied \\ Economics, University of Cordoba, 14071, Córdoba, Spain; ramon.rueda@uco.es (R.R.L.); $\underline{\text { mppriego@uco.es }}$ \\ (M.P.P.); d52gagam@uco.es (MB.GM.G.) \\ * Correspondence: ramon.rueda@uco.es
}

\begin{abstract}
The cultural and historical heritage of a city is a major resource to attract tourists. Therefore, reaching out to perceive and identify the characteristics of persons visiting a locality attracted by their property is relevant for the purpose of better meeting their expectations and needs. This research focuses on knowing the perceptions, motivations and satisfaction of women visiting Cordoba (Spain). Thus, on the basis of the questionnaire carried out on women visiting Cordoba during the months of June and November 2019, a statistical analysis has been made. Using various multivalent case-grouping techniques, tourist segments with similar perceptions of cultural heritage have been detected. Moreover, non-parametric statistical techniques have showed up significant differences between the valuations obtained in the various segments. This analysis has exposed a segment of women who, known as absorbent tourists, are characterized by the high cultural motivation to visit the city of Cordoba linked to the heritage they have visited. The conclusions obtained should be useful in adjusting the city's tourist supply to the specific demand of a population sector such as women visiting the city.
\end{abstract}

Keywords: tourist perception; tourist motivation, tourist satisfaction, gender, segmentation, Cordoba

\section{Introduction.}

For the tangible and intangible heritage of a particular place, to be included in the Intangible Cultural Heritage (ICH), in the List of Heritage of Humanity at Risk or in the World Heritage Site (WHS) -lists annually published by the United Nations Educational, Scientific and Cultural Organization (UNESCO)- means, in addition to great recognition, the acquisition of a value of existence to be protected for future generations.

Each of these inscriptions brings with it a powerful element of attraction for tourism [1,2]. It is precisely the subject of debate, to reach out to and identify those and the tourists who visit these places attracted to their property status. Indeed, it is essential for this research to know whether it is because of their registration at WHS, and therefore a particular place is visited [3].

At the same time, it is relevant for this research to identify and determine, in a disaggregated way, what women's perceptions and tourist experiences are. Research on gender differences in tourism has been addressed from various perspectives [4-6]. Thus, differentiating the perceptions and tourism experiences that women have on men, makes it possible to better understand the same and thus better to meet women's expectations from the tourist sector [7-9].

On the other hand, scientific literature uses two models for the segmentation of foreign tourism at WHS and this research will try to innovate, using a segmentation model based on the previous two. The first model to which it refers is McKercher [10]. This model uses two different dimensions for segmentation: (1) the importance it has for tourists when they make a decision on the specific 
place to visit, cultural motivations; (2) the satisfaction of the expectations covered by the destination visited in those persons. The McKercher model allows five different groups of visitors to be obtained: serendipitous cultural tourist, purposeful cultural tourist, incidental cultural tourist, sightseeing cultural tourist y casual cultural tourist [10]. The second model is [11]. Guided by more emotional elements, these authors use two aspects for segmentation: on the one hand they study the relationship established between destination and visitor in the field of emotions, on the other hand, the relationship between personal inheritance and the patrimonial heritage of destiny. The Poria model obtains three typologies of visitors: (1) people visiting places as they are considered part of their cultural heritage, (2) persons who have no cultural link to the places they visit and, finally, 3) persons who are unaware or unaware, consciously or unconsciously, of cultural linkage to the place visited.

\section{Theoretical Background.}

\subsection{Heritage tourism}

There is a relationship between the monumental and artistic heritage and the tourist people visiting it, which is recognized in academic literature linked to heritage tourism [3]. On the basis of this relationship, visits to heritage destinations which cause a particular living experiences are known as heritage tourism. In other words, beyond recreational practice, which can be obtained from other destinations, the visit to WHS areas represents for the visiting person, a reunion with his own cultural heritage [12]. The patterns of the visit are drawn up by the perception that people have of destiny as part of their heritage. This visit would therefore be designed to seek and perceive the heritage of the place for the visitors [11]. In short, we will have characteristic behavior, different from the other people, if we feel a special link, whether historical or cultural, to the place we visit.

In the case of women, admitting and identifying this behavior, it will lead to different strategies, by private companies and different governments, to better manage destinations and improve tourism [9].

In this case, it is not something new to talk about cultural tourism. As early as the 17th century, English nobility had as a suit to enhance travel to those they called "Great Tour". These travels were understood as visits to destinations highlighted in their heritage interest; so that, on their return, they were personally enriched and more widely intellectual training, through knowledge of European heritages sites and landscapes [13].

Over time, the heritage destinations are among the most visited, especially the places registered by UNESCO as the Heritage of Humanity. This type of cultural tourism has been expanding its social base, so that the flow of people interested in visiting heritages sites has been gradually increasing [14].

It follows from this statement that such listing is similar to a quality stamp or a mark that makes a place visit talking from a tourist point of view $[15,16]$; it is as if the place acquires with its inclusion, an added value more similar to universal excellence, making it more attractive to tourism [14].

Thus, a clear correlation has been observed between the inclusion in one of the UNESCO lists (although it is rather intended to preserve and preserve such sites) and the number of people visiting a destination, especially foreign nationals [17].

Indeed, this increase in visits naturally entails an increase in tourism revenues, which entails a change in management of the area, both environmental and business [3]. In this regard, academic literature supporting the relationship between tourism and the heritage legacy, particularly in WHS, may be cited, for example, by the publications of Remoaldo et al. [18], Antón et al. [19] or Vong and Ung [20]. Studies are also focused on establishing this relationship in various countries such as Ecuador [21], Macao [2,20], China [22], Vietnam [3] or Portugal [23].

This is why, according to Lourenço-Gomes et al. [24], a close link can be established between tourism and the cultural and patrimonial heritage endorsed by UNESCO. Thus, within the heritage tourism category, a subcategory could be established, called "tourism in World Heritage sites". 
Furthermore, while the literature that supports the same relationship with the Inmaterial Heritage of Humanity is not so extensive, research such as Gómez et al. [25] can be highlighted as to the Tango dance in Buenos Aires or González Santa-Cruz and López-Guzmán [26] in relation to the study on how the "Fiesta de los Patios de Cordoba" involves a motivation to travel to the city.

As indicated by Del Barrio et al. [27], the idea of cultural and heritage legacy has followed an evolution since the end of the last century, through two different ways: (1) increasing the Heritage of Humanity. Although registration of monuments, historical buildings or archaeological sites were restricted, other cultural options such as gardens, traditional manufacturing techniques or rural areas were possible; (2) adding other elements that seek the recognition of different collective identities such as folklore or customs and which, of course, form an indivisible part of the cultural legacy of peoples.

As is assumed, this has meant that the relationship between the Heritage Sites of Humanity (both material and intangible) and tourism, expanded its scientific typology to an increasingly wider field, allowing both cultural development and sustainable tourism development [28]. Thus, scientific literature has also been increased, highlighting among other studies such as Timothy and Boyd [29], Timothy [30], Di Giovine [31], Park [32].

Regardless of the environment in which they occur (cultural or natural) or destination location, heritage tourism refers only to activities arising from visiting a particular place and experiences experienced therein [3]; in other words, the traveling person seeks precisely the link of his roots to that heritage legacy [18]. That is why, sometimes, the designation as WHS is made to encourage visits to that destination, because of the authenticity sought in travel or the special experience that can be enjoyed [32,33].

According to Su and Wall [34], two lines of research can be drawn up for the study of heritage tourism: the definition and segmentation of the legacy, both historical and property, and the legacy linking tourist flows to historical and patrimonial legacy. These two lines finally provide two different answers to what heritage tourism is [11]: the one based on visits to places where there is a significant material heritage, and the one based on the perception of tourists about these places linked to their own personal inheritance.

For all of this, and continuing with Poria et al [12], the visit to a place with a historic legacy has two components linked to tourism, the opportunity to visit a place of recognized excellence or the reunion with part of the cultural heritage itself [35].

Based on the review of the literature carried out, the hypothesis that is to be contrast is: tourist women show different emotional perceptions as to whether they visit the city of Cordoba $\left(\mathrm{H}_{1}\right)$.

\subsection{Tourist segmentation.}

As Muñoz-Fernández et al. [36] indicate, a correct segmentation of tourists visiting a WHS destination is essential to manage such visits in a suitable way and then to achieve differential services covering all possible demands. For a correct segmentation, it is necessary to know its behavior, perceptions and motivations [3] in addition to specific predispositions and knowledge [37]. If this segmentation is carried out properly, it will be easy to identify tourism which comes as a simple visitor [38] of the heritage tourist who expressly acknowledge the place as the Heritage of Humanity.

As regards segmentation, Chen and Huang [39] reviews various investigations carried out to identify possible typologies of visitors as regards the segmentation of the latter in asset destinations.

Firstly, four typologies of tourist can be distinguished, according to Silberberg [40]: accidental cultural tourist, adjunct cultural tourist, in part cultural tourist and greatly cultural tourist.

On the other hand, Poria et al. [11], it conducts a triple segmentation based on the perception of visitors' own heritage, thus based on the relationship between tourist and destination. In this way, it is possible to differentiate visitors who are not related to their legitimate heritage, visitors who want to complete and deepen the knowledge of the estate and, finally, visitors who do not feel identification of the site visiting their own heritage.

One of the most important typologies is that of McKercher [10] which proposes five typologies of visitors which obtains to analyze two different dimensions; on the one hand, the extent and depth of 
the knowledge that is taken from the site and therefore the cultural motivations that are taken to visit a particular place. So, these five typologies would be: incidental cultural tourist, casual cultural tourist, serendipitous cultural tourist, sightseeing cultural tourist and purposeful cultural tourist.

This segmentation can also be found in studies such as Nguyen and Cheung [3], Chen and Huang [39] and McKercher and Du Cros [41].

Finally, the segmentation of Ramires et al. [23] introduces two elements to perform their work as they are, on the one hand, culture and leisure and economic value. Thus, three typologies of tourism would appear: conventional, spontaneous and absorptive.

\subsection{Sociodemographic profile of tourists.}

The sociodemographic profile is being studied by various research into tourist preferences, in particular gender, age, level of training and income [42].

As regards gender variable, there is a dispute; since, while some research concludes that women have greater preference for heritage tourism $[3,18,20,23]$, other empirical studies conclude otherwise $[14,19,39,43]$. However, these researches indicate that there are no significant gender differences.

On the age variable, most scientific literature collects that visitors are young. Chen and Huang [39] set the age of visitors between 21 and 35 years, Remoaldo et al., [18] over 26 and 45 years and Antón et al. [19]. Correia et al. [14] and Ramires et al. [23] raise this age range to over 45 years for tourists visiting Lisbon and Porto. This difference in age ranges leads to the fact that the older the older the emotional experiences perceived by people may be.

The variable training on its part, has little controversial, most studies conclude that visitors from heritages sites generally have university academic training $[14,18,19,23,40,44]$ and are also an attractive destiny for students who attend them on study trips, and this group of visitors should therefore be included in the analysis of the phenomenon [39].

In addition, previous investigations agree that tourists with prefects of heritage destinations have, except students, middle-high income levels [14,23,39,44,45]. According to the revision of the literature carried out, the following hypothesis are being made, increasing age makes women's emotional experience increasing $\left(\mathrm{H}_{2}\right)$ and higher education is a factor that increases women's emotional experience $\left(\mathrm{H}_{3}\right)$.

\subsection{Assessment of destiny attributes.}

Those elements that attract tourists to a particular destination and define it and differ from other destinations are called attributes [46]. The attributes, due to their unique character, have a huge weight in positioning the mark of the tourist destination [47]; therefore, their identification and development is necessary to encourage tourists to choose them as destination [48]. In addition, these attributes largely explain the attributes of tourists to places, as they are key elements in travel experience $[49,50]$. In addition, when assessing tourist satisfaction with destiny, the overall assessment of the evaluation of multiple attributes from two perspectives should be distinguished; the first is linked to desire and emphasizes emotivity, while the second relates to tourists' expectations in their consumer facet [14]. Assessment of multiple attributes can contribute to adjustments. These can lead to improved quality of travel experience, through improved products and services and the implementation of effective destination strategies. However, the levels of overall satisfaction are increasing, positively influencing tourist loyalty [51-54]. The question to be determined, according to scientific literature, is what the relevant attributes to are effectively evaluate the impressions of a tourist to the place he visits and thus to identify key mechanisms that focus them $[51,53,55,56]$.

From this revision of literature, the hypothesis that is to be contrast is: women who demonstrate deeper emotional experience in relation to the rich heritage they visit have a positive assessment of tourist resources $\left(\mathrm{H}_{4}\right)$.

\section{Methodology.}




\subsection{Questionnaire and proceeding.}

The methodology used for the conduct of this investigation is based on a structured questionnaire to a representative sample of women who visited the city of Cordoba (Spain). Within the options available for the collection of the information, the design of a closed questionnaire was chosen to be self-administered. In order to ensure the validity of the questionnaire, the formulation of the items is based on different previous investigations $[11,14,18]$. From an initial set of items, a three-stage cleansing process was followed: (1) a tourist researcher analyzed the proposed items; (2), the resulting questionnaire was reviewed by several responsible for tourism activity in the city; (3), a pretest was made to 20 tourists. During the purification phase, it was found that some questions were not easily understood by respondents, correcting them later, and after assessing the questions and validity of the questionnaire, to perform a final field work.

The final version of the questionnaire was intended: (1) to ensure the maximum clarity of questions and the greatest adjustment of the answers to achieve the proposed objectives, (2) as much as possible to avoid overextending the interview. The questionnaires were carried out at different locations in the historical sites of Cordoba, assuming that the interviewee had been around the city for a certain time and could therefore give a strong opinion [14,18].

As for its structure, it is divided into three big blocks. The first, with closed questions, aimed at collecting the characteristics of the visit: number of pre-city visits, time of stay, type of establishment he uses to overnight, medium for which he has been aware of the city, etc. The second, by a five-point Likert scale, focused on: motivations to visit the city of Cordoba, emotional perceptions of historical and monumental heritage visited, assessment of the main attributes related to the visit, level of satisfaction achieved based on experience and attitudinal loyalty. Finally, a third subparagraph, with closed questions, obtains the sociodemographic characteristics of tourists: age, gender, economic level or degree of training...

A total of 437 surveys were carried out for women, of which 422 were valid, completed between June and November 2019. A non-probabilistic technical sampling was used, commonly used in this type of research where interviewees are available for surveys in a given space and time [57]. No prior studies were strategically supported by age, training, nationality or any other variable, since they did not have prior studies to support this strategic. The rate of refusal to the questionnaire was low and not significant according to any variable. In no case, the duration of the survey was more than 10 minutes.

\subsection{Sampling and Sampling error.}

The specific framework for our research is the tourist woman visiting the city of Cordoba, regardless of whether or not she is overnight or whether or not she visits other places in the Andalusian region. The number of tourists visiting this city was 967,503 persons in 2019, according to reports of the Cordoba Tourist Observatory [58], of whom $50 \%$ are women. Therefore, and based on this number of visitors, the sample error for a $95 \%$ confidence level would be $\pm 4.77 \%$. This error would show the diversion of the selected sample in relation to the true characteristics, features, behavior, qualities of the population under study, the number of tourists arriving in the city of Cordoba if random sampling had been carried out. On the contrary, field work has been designed under sampling of convenience, where people are available at one place and at a time for survey.

\subsection{Data analysis.}

Tabulation and statistical analysis of data has been carried out using the SPSS software V. 24 . The Alpha de Cronbach has been used as a statistician to validate internal consistency and thus reliability of the responses obtained. Subsequently, various multivariant case-grouping techniques have been applied to identify segments with similar perceptions of cultural heritage. Following this, and with the aim of validating the relevance of clusters obtained in the segmentation, discriminatory analysis has been carried out. Finally, in order to analyze the possible existence of statistically significant differences in the scores of items between the different segments, non-parametric 
statistical techniques ( $\mathrm{H}$ of Kruskal Wallis and U of Mann-Whitney) have been used because the characteristics of the sample do not meet the requirements for parametric analysis.

\section{Analysis and discussion.}

\subsection{Segmentation of tourists.}

The basis for segmentation is based on the perception of historical heritage by tourists visiting the city of Cordoba. Specifically, on the emotions received when visiting it, as set out in the Poria model [11]. The four items comprising the above model, which are listed in Table 1, present an Alpha de Cronbach coefficient of 0.762 , indicating a good internal consistency of the scale values.

Table 1: Segments based on the perception of historical heritage

\begin{tabular}{|c|c|c|c|c|c|}
\hline \multirow{2}{*}{ Perception } & \multicolumn{3}{|c|}{ Tourist Clusters } & \multicolumn{2}{|c|}{$\begin{array}{c}\text { H-Kruskalw } \\
\text { Wallis }\end{array}$} \\
\hline & $\begin{array}{c}1 \\
24.4 \% \\
\end{array}$ & $\begin{array}{c}2 \\
50.5 \% \\
\end{array}$ & $\begin{array}{c}3 \\
25.1 \% \\
\end{array}$ & $\sqrt{\chi^{2}}$ & Sig. \\
\hline $\begin{array}{l}\text { The visit to the historical heritage of the city } \\
\text { has contributed to my education }\end{array}$ & $3.56^{(*)}$ & $4.43^{(*)}$ & $4.75^{(*)}$ & 126.804 & $<0.000$ \\
\hline $\begin{array}{l}\text { The visit to the historical heritage of the city } \\
\text { has made me excited }\end{array}$ & $\left.3.31^{*}\right)$ & $4.38^{(*)}$ & $\left.4.98^{*}\right)$ & 227.828 & $<0.000$ \\
\hline During the visit, I felt part of the heritage & $2.80^{(*)}$ & $3.76^{(*)}$ & $5^{(*)}$ & 292.961 & $<0.000$ \\
\hline $\begin{array}{l}\text { The visit to the historical heritage of the city } \\
\text { has made me feel good }\end{array}$ & $3.78^{(*)}$ & $4.49^{(*)}$ & $4.93^{(*)}$ & 143.192 & $<0.000$ \\
\hline
\end{tabular}

Source: own elaboration

The drafting of segments based on theory has been carried out through non-hierarchical analysis of conglomerates. However, given the exploratory nature of the technique (Hair, Anderson, Tatham and Black, 1999), the $H$ test of Kruskal and Wallis [59] has been used to verify its validity.

Table 1 show the three tourist segments obtained from the four items considered for the study. In addition, it also shows the results of statistical $\mathrm{H}$ of Kruskal Wallis, which reveals inequality in the items that make up the emotional perception of tourists from the different segments established. For its part, and since the previous test does not allow for differences between couples of segments, the $\mathrm{U}$ of Mann and Whitney [60] is used, which reveals statistically significant differences in the different combinations of segments compared to two.

For the three clusters obtained, and following the classification of Ramires et al. [23], the first one has to cover $24.4 \%$ of tourists surveyed, characterized by showing a perception of the unremarkable emotional experience, known as "spontaneous tourists". The second group consists of $50.5 \%$ of those respondents, named this group "conventional tourists" and, finally, the third of the clusters, composed of the remaining $25.2 \%$ and to be called "absorptive tourists".

The results obtained show the validation of one of the hypotheses presented: tourist women show different emotional perceptions as to whether they visit the city of Cordoba $\left(\mathrm{H}_{1}\right)$.

\subsection{Socio-economic characteristics of women visiting the city of Cordoba.}

Table 2 show the sociodemographic profile of the woman tourist visiting the city of Cordoba. It can be observed as women surveyed are mostly under 30 years of age, with this characteristic in the segments analyzed individually. While it should be noted that, proportionally analyzed, tourists with the greatest cultural interest in destination have higher ages (Kruskal-Wallis statistical $\mathrm{H}=17,817 ; \mathrm{p}=0,000)$. This result corroborates the assumption that women's emotional experience is increasing with age $\left(\mathrm{H}_{2}\right)$.

Table 2: Socio-demographic profile of tourist women visiting Cordoba. 


\begin{tabular}{|c|c|c|c|c|c|}
\hline & & $\begin{array}{c}\text { Spontaneous } \\
\text { tourists } \\
\mathrm{N}=103\end{array}$ & $\begin{array}{c}\text { Conventional } \\
\text { tourists } \\
\mathrm{N}=\mathbf{2 1 3}\end{array}$ & $\begin{array}{c}\text { Absorptive } \\
\text { tourists. } \\
\mathrm{N}=106\end{array}$ & $N=422$ \\
\hline \multirow{6}{*}{$\begin{array}{c}\text { Age } \\
(\mathrm{N}=421)\end{array}$} & Under 30 years of age & $48.5 \%$ & $31 \%$ & $27.6 \%$ & $34.4 \%$ \\
\hline & 30-39 years old & $18.4 \%$ & $16.9 \%$ & $14.3 \%$ & $16.6 \%$ \\
\hline & $40-49$ years old & $12.6 \%$ & $22.1 \%$ & $17.1 \%$ & $18.5 \%$ \\
\hline & $50-59$ years old & $17.5 \%$ & $18.8 \%$ & $23.8 \%$ & $19.7 \%$ \\
\hline & 60 years old or more & $2.9 \%$ & $11.3 \%$ & $17.1 \%$ & $10.7 \%$ \\
\hline & Primary education & $3.9 \%$ & $3.8 \%$ & $4.8 \%$ & $4 \%$ \\
\hline \multirow{3}{*}{$\begin{array}{l}\text { Educational level } \\
\qquad(\mathrm{N}=418)\end{array}$} & Secondary education & $24.3 \%$ & $16.5 \%$ & $18.1 \%$ & $18.8 \%$ \\
\hline & University education & $37.9 \%$ & $51.9 \%$ & $54.3 \%$ & $49 \%$ \\
\hline & Master/PhD & $34 \%$ & $26.9 \%$ & $22.9 \%$ & $27.6 \%$ \\
\hline \multirow{10}{*}{$\begin{array}{c}\text { Professional } \\
\text { activity }(\mathrm{N}=419)\end{array}$} & Liberal professional & $14.7 \%$ & $7.1 \%$ & $10.5 \%$ & $9.8 \%$ \\
\hline & Entrepreneur & $1 \%$ & $3.3 \%$ & $2.9 \%$ & $2.6 \%$ \\
\hline & Public servant & $8.8 \%$ & $6.6 \%$ & $10.5 \%$ & $8.1 \%$ \\
\hline & Full-time employee & $42.2 \%$ & $41.5 \%$ & $37.1 \%$ & $40.6 \%$ \\
\hline & Part-time employee & $3.9 \%$ & $6.6 \%$ & $3.8 \%$ & $5.3 \%$ \\
\hline & Self-employed & $2.9 \%$ & $5.7 \%$ & $6.7 \%$ & $5.3 \%$ \\
\hline & Student & $15.7 \%$ & $9.9 \%$ & $9.5 \%$ & $11.2 \%$ \\
\hline & Unemployed & $2.9 \%$ & $4.2 \%$ & $1.9 \%$ & $3.3 \%$ \\
\hline & Retired/a & $5.9 \%$ & $11.3 \%$ & $15.2 \%$ & $11 \%$ \\
\hline & Household work & $2 \%$ & $3.8 \%$ & $1.9 \%$ & $2.9 \%$ \\
\hline \multirow{3}{*}{$\begin{array}{l}\text { Country of origin } \\
\qquad(\mathrm{N}=422)\end{array}$} & National & $21.4 \%$ & $28.6 \%$ & $31.1 \%$ & $27.5 \%$ \\
\hline & Foreigners & $78.6 \%$ & $71.4 \%$ & $68.9 \%$ & $72.5 \%$ \\
\hline & Less than 700 euros & $4.8 \%$ & $4.2 \%$ & $4.5 \%$ & $4.4 \%$ \\
\hline \multirow{5}{*}{$\begin{array}{c}\text { Income } \\
(€ / \text { month }) \\
(\mathrm{N}=294)\end{array}$} & From 700 to 1,000 euros & $4.8 \%$ & $6.9 \%$ & $6 \%$ & $6.1 \%$ \\
\hline & From 1,001 to 1,500 euros & $16.9 \%$ & $16 \%$ & $17.9 \%$ & $16.7 \%$ \\
\hline & From 1,501 to 2,500 euros & $25.3 \%$ & $30.6 \%$ & $28.4 \%$ & $28.6 \%$ \\
\hline & From 2,500 to 3,500 euros & $20.5 \%$ & $17.4 \%$ & $13.4 \%$ & $17.3 \%$ \\
\hline & More than 3,500 euros & $27.7 \%$ & $25 \%$ & $29.9 \%$ & $26.9 \%$ \\
\hline
\end{tabular}

Source: own elaboration

Focusing attention on the professional category of respondents, most of them are full-time employees, followed by students, something that is usually common in WHS cities [39].

The level of academic training for women in the field is high, with $76.6 \%$ of women surveyed, graduating or graduating university grade. In addition, it should be noted that the educational level described does not differ from different groups of established tourists, $\mathrm{H}_{3}$ cannot be confirmed, which states that travelers who have greater cultural interest in a WHS destination (Kruskal-Wallis statistical $\mathrm{H}=0.933 ; \mathrm{p}=0.627$ ).

It is also noted that $72.5 \%$ of women tourists are extraordinary, with little ratio of their origin to the cultural interest of the city of Cordoba and the emotional linkage shown (contingency coefficient $=0.081 ; \mathrm{p}=0.248$ ).

In the case of family monthly income, $28.6 \%$ of the respondents are between EUR 1,500 and EUR 2500, reaching an income of more than EUR 3,500, 26.9\% of these. This can be said that tourists visiting the city of Cordoba amount to medium-high purchasing power. In addition, there are no statistically significant differences in income level for segments obtained from cultural interest and emotional linkages (Kruskal-Wallis statistical $\mathrm{H}=0.327$; $\mathrm{p}=0.849$ ).

Finally, it is worth noting the low rate of repetition of the visit, as only $30 \%$ of tourists claim to have visited the city earlier.

\subsection{Value received by women visiting the city of Cordoba.}

Table 3 show the scores obtained from the items included in the questionnaire to analyze the assessment obtained by the city's tourist resources, both for each segment obtained and for the total sample. For its part, Cronbach's alpha (0.797) reveals good internal consistency in data. Similarly, 
Friedman's $X^{2}$ statistician (1241.74), whose critical value is less than 0.001 shows that the averages of the elements are not equal.

Specifically, the attributes that differ in each tourist group are those that are at the first five ranking posts that are collected in Table 3. Thus, it can be said that attributes that contribute greatest measurement to the satisfaction of tourists include: "the historical and monumental center", "the conservation of monumental and artistic heritage", "the beauty of the city", "care and cleaning of the city", "citizen security" and "hospitality of residents".

On the contrary, the attributes that obtain lower valuations are: "supplementary leisure offer", "care and quality of tourist guides", "public transport services" and "accessibility to flagship buildings and monuments". They pose a disadvantage over other destinations, while an opportunity to improve the excellence of the city of Cordoba as a destination.

From the above, it is possible to contrast partially the hypotheses that women who demonstrate deeper emotional experience in relation to the rich heritage they visit have a positive assessment of tourism resources of destiny $\left(\mathrm{H}_{4}\right)$.

Table 3: Assessment of tourist attributes

\begin{tabular}{|c|c|c|c|c|c|c|c|}
\hline \multirow[b]{2}{*}{ Attributes } & \multirow{2}{*}{$\begin{array}{l}\text { Spontaneous } \\
\text { tourists } \mathrm{N}=103\end{array}$} & \multirow{2}{*}{$\begin{array}{c}\text { Conventional } \\
\text { tourists } \\
\mathrm{N}=213 \\
\end{array}$} & \multirow{2}{*}{$\begin{array}{l}\text { Absorptive } \\
\text { tourists } \\
\mathrm{N}=106\end{array}$} & \multicolumn{2}{|c|}{ H-Kruskal Wallis } & \multirow{2}{*}{$\begin{array}{c}\text { Total } \\
N=422\end{array}$} & \multirow[b]{2}{*}{$R k g$} \\
\hline & & & & $\chi^{2}$ & Sig. & & \\
\hline $\begin{array}{l}\text { The historical and } \\
\text { monumental center }\end{array}$ & $4.33^{(*)}$ & $4.58^{(*)}$ & $4.76^{(*)}$ & 26.716 & $<0.000$ & 4,56 & 1 \\
\hline $\begin{array}{l}\text { Conservation of } \\
\text { monumental and artistic } \\
\text { heritage }\end{array}$ & $4.18^{(*)}$ & $4.35^{(*)}$ & $4.74^{(*)}$ & 34.265 & $<0.000$ & 4.41 & 2 \\
\hline The beauty of the city & $4.27^{(*)}$ & $4.39^{(*)}$ & $4.59^{(*)}$ & 17.302 & $<0.000$ & 4.41 & 2 \\
\hline $\begin{array}{l}\text { Accessibility to flagship } \\
\text { buildings } \\
\text { monuments }\end{array}$ & 3.49 & 3.32 & 3.31 & 0.004 & 0.998 & 3.36 & 11 \\
\hline Tourist information & 3.26 & 3.45 & 3.52 & 5.66 & 0.059 & 3.42 & 9 \\
\hline $\begin{array}{l}\text { Attention and quality of } \\
\text { tourist facilities }\end{array}$ & 3.30 & 3.69 & 3.43 & 11.201 & 0.004 & 3.53 & 8 \\
\hline $\begin{array}{l}\text { Attention and quality of } \\
\text { restaurants and bars }\end{array}$ & $3.35^{(*)}$ & 3.63 & 3.58 & 9.022 & 0.011 & 3.55 & 7 \\
\hline $\begin{array}{l}\text { Attention and quality of } \\
\text { tourist guides }\end{array}$ & 2.74 & 2.76 & 2.90 & 1.242 & 0.537 & 2.79 & 14 \\
\hline $\begin{array}{l}\text { Diversity and quality of } \\
\text { local gastronomy }\end{array}$ & 3.44 & 3.42 & 3.37 & 0.249 & 0.883 & 3.41 & 10 \\
\hline $\begin{array}{l}\text { Opportunity to purchase } \\
\text { crafts and traditional } \\
\text { food items }\end{array}$ & 3.06 & 2.99 & 3.20 & 2.194 & 0.334 & 3.06 & 12 \\
\hline Additional leisure offer & 2.49 & 2.53 & 2.59 & 0.174 & 0.917 & 2.53 & 14 \\
\hline Citizen Security & $3.55^{(*)}$ & 3.87 & 3.86 & 11.842 & 0.003 & 3.79 & 4 \\
\hline $\begin{array}{l}\text { Care and cleaning of the } \\
\text { city }\end{array}$ & $\left.3.82^{*}\right)$ & $\left.4.09^{*}\right)$ & $4.30^{(*)}$ & 19.083 & $<0.000$ & 4.08 & 3 \\
\hline Resident hospitality & $\left.3.41^{*}\right)$ & 3.87 & 3.90 & 18.823 & $<0.000$ & 3.77 & 5 \\
\hline Public transport services & 2.72 & 2.75 & 2.77 & 0.278 & 0.87 & 2.75 & 13 \\
\hline $\begin{array}{l}\text { Quality-price ratio of the } \\
\text { city }\end{array}$ & 3.50 & 3.64 & 3.81 & 6.828 & 0.033 & 3.65 & 6 \\
\hline
\end{tabular}

Notes: $\left(^{*}\right)$ Values present significant differences in two of the three groups of averages, having applied to assess the U-Mann-Whitney test.

Source: own elaboration

\section{Conclusions.}

As a place by UNESCO as the Heritage of Humanity, there is a cultural recognition and commitment to conserve the place, and, on the other hand, there is an important attraction for the 
promotion of destination for a particular typology of tourist and therefore the need to manage the place properly.

The cultural potential of the city of Cordoba requires studies to produce results and search for key issues that are essential in planning and developing strategies for improvement or tourism promotion.

Differential plans in tourism supply and city tourist strategies go through a thorough description of tourists visiting the city. This means not only analyzing sociodemographic variables but also carrying out an analysis of the perception that tourists have been visited by tourists, their motivations, their interests or expectations.

This research makes a contribution to the existing academic literature on the links between tourist women and the historical and monumental heritage they visit, as well as the tourist behavior of tourist women. With regard to women, on the one hand and according to the Poria model, the study of what emotions they perceive when visiting Cordoba's historical and monumental heritage; on the other hand, and according to the McKercher model, the largest or less cultural motivation has been found in the decision to visit Cordoba. However, according to Ramires' classification, a model is obtained showing the empirical evidence of three typologies of foreign tourists that are considered valid to segment them in the city of Cordoba as a tourist destination WHS: Spontaneous tourists, conventional tourists and absorbent tourists.

Of the three identified clusters, linking the heritage visited and cultural motivation by destination plays a relevant role among the absorbent tourist.

As regards the analysis of satisfaction, one of the main contributions of this investigation is to note that the level of satisfaction towards a WHS destination, such as Cordoba, is influenced by motivations for going to the city.

The results achieved show that culture and heritage contribute more to the satisfaction shown with destiny, in our Cordoba case. The greatest interest is translated, at the same time, into particularly different perceptions as regards destination's tourist attributes, with a greater appreciation of cultural and property resources, as well as those related to the conservation, care and impairment of the city.

As a practical implementation of this research, it is important to understand, for women, the differentiating characteristics which, as tourists, present. This allows you to know the assessment they make of your visit to Cordoba. This can be useful in designing a tourist supply and tourist products, which, in accordance with the principles of sustainable management of historical and monumental heritage, can meet women's expectations and needs specifically.

The tourism sector, on the demand side, has only limited limitations to this investigation, since the results obtained may cause difficulties in transferring to other actors, public or private, in the field of tourism in Cordoba. Therefore, a future research line would be aimed at assessing the activity that these other actors, public or private, can develop in the tourist sector in Cordoba.

Author Contributions: Conceptualization, A.L.E., R.R.L., M.P.P. and MB.GM.G.; Methodology, R.R.L. and MB.GM.G. Software, MB.GM.G.; Formal Analysis, A.L.E., R.R.L., M.P.P. and MB.GM.G.; Resources, R.R.L. and MB.GM.G. Writing-Original Draft Preparation, A.L.E., R.R.L., M.P.P. and MB.GM.G; Writing-Review \& Editing, A.L.E., R.R.L., M.P.P. and MB.GM.G; Supervision, R.R.L; Project Administration, R.R.L; All authors have read and agreed to the published version of the manuscript.

Acknowledgments: The authors of this article would like to thank the collaboration of the Municipal Institute of Tourism (IMTUR) of Cordoba City Council for its help in carrying out this research. Thank you.

Conflicts of Interest: The authors declare no conflict of interest.

\section{References}


1. Adie, B.A. Franchising our heritage: The UNESCO world heritage brand. Tourism Management Perspectives 2017, 24, 48-53, doi:10.1016/j.tmp.2017.07.002.

2. Io, M.-U. Understanding the core attractiveness of performing arts heritage to international tourists. Tour. Geogr. 2019, 21, 687-705, doi:10.1080/1416688.2019.1571096.

3. Nguyen, T.H.H.; Cheung, C. The classification of heritage tourists: A case of Hue city, Vietnam. Journal of Heritage Tourism 2014, 9, 35-50, doi:10.1080/1743873X.2013.818677.

4. Rasoolimanesh, S.M.; Khoo-Lattimore, C.; Md Noor, S.; Jaafar, M.; Konar, R. Tourist engagement and loyalty: gender matters? Current Issues in Tourism 2020, 10.1080/13683500.2020.1765321, 1-15, doi:10.1080/13683500.2020.1765321.

5. Wang, R.; Hao, J.X. Gender Difference on Destination Image and Travel Options: An Exploratory Text-Mining Study. In Proceedings of 2018 15th International Conference on Service Systems and Service Management, ICSSSM 2018.

6. Yang, E.C.L.; Khoo-Lattimore, C.; Arcodia, C. A systematic literature review of risk and gender research in tourism. Tourism Manage. 2017, 58, 89-100, doi:10.1016/j.tourman.2016.10.011.

7. McGehee, N.G.; Kim, K.; Jennings, G.R. Gender and motivation for agri-tourism entrepreneurship. Tourism Manage. 2007, 28, 280-289, doi:10.1016/j.tourman.2005.12.022.

8. Um, S.; Crompton, J.L. The Roles of Perceived Inhibitors and Facilitators in Pleasure Travel Destination Decisions. Journal of Travel Research 1992, 30, 18-25, doi:10.1177/004728759203000303.

9. Wang, C.; Qu, H.; Hsu, M.K. Toward an integrated model of tourist expectation formation and gender difference. Tourism Manage. 2016, 54, 58-71, doi:10.1016/j.tourman.2015.10.009.

10. McKercher, B. Towards a classification of cultural tourists. International journal of tourism research 2002, 4, 29-38, doi:10.1002/jtr.346.

11. Poria, Y.; Butler, R.; Airey, D. The core of heritage tourism. Annals of tourism research 2003, 30, 238-254, doi:10.1016/S0160-7383(02)00064-6.

12. Poria, Y.; Reichel, A.; Biran, A. Heritage site management: Motivations and expectations. Annals of tourism research 2006, 33, 162-178, doi:10.1016/j.annals.2005.08.001.

13. Turner, L.; Ash, J. La Horda Dorada. El turismo internacional y la periferia del placer. Editorial Endymion, Madrid, España: 1991.

14. Correia, A.; Kozak, M.; Ferradeira, J. From tourist motivations to tourist satisfaction. International Journal of Culture, Tourism, and Hospitality Research 2013, 7, 411-424, doi:10.1108/IJCTHR-05-2012-0022.

15. Hassan, A.; Rahman, M. World Heritage site as a label in branding a place. Journal of Cultural Heritage Management and Sustainable Development 2015, 5, 210-223, doi:10.1108/JCHMSD-01-2014-0002.

16. Mariani, M.M.; Guizzardi, A. Does designation as a UNESCO world heritage site influence tourist evaluation of a local destination? Journal of Travel Research 2019, 59, 22-36, doi:10.1177/0047287518821737.

17. Breakey, N.M. Studying World Heritage visitors: the case of the remote Riversleigh Fossil Site. Visitor Studies 2012, 15, 82-97, doi:10.1080/10645578.2012.660845.

18. Remoaldo, P.; Vareiro, L.; Cadima Ribeiro, J.; Freitas Santos, J. Does Gender Affect Visiting a World Heritage Site? Visitor Studies 2014, 17, 89-106, doi:10.1080/10645578.2014.885362.

19. Antón, C.; Camarero, C.; Laguna-García, M. Towards a new approach of destination loyalty drivers: Satisfaction, visit intensity and tourist motivations. Current Issues in Tourism 2017, 20, 238-260, doi:10.108/13683500.2014.936834. 
20. Vong, L.T.-N.; Ung, A. Exploring critical factors of Macau's heritage tourism: What heritage tourists are looking for when visiting the city's iconic heritage sites. Asia Pacific Journal of Tourism Research 2012, 17, 231-245, doi:10.1080/10941665.2011.625431.

21. López-Guzmán, T.; Torres Naranjo, M.; Pérez Gálvez, J.C.; Carvache Franco, W. Segmentation and motivation of foreign tourists in world heritage sites. A case study, Quito (Ecuador). Current Issues in Tourism 2019, 22, 1170-1189, doi:10.1080/13683500.2017.1344625.

22. Wang, Y.; Huang, S.; Kim, A.K. Toward a framework integrating authenticity and integrity in heritage tourism. Journal of Sustainable Tourism 2015, 23, 1468-1481, doi:10.1080/09669582.2015.1047375.

23. Ramires, A.; Brandao, F.; Sousa, A.C. Motivation-based cluster analysis of international tourists visiting a World Heritage City: The case of Porto, Portugal. Journal of Destination Marketing $\mathcal{E}$ Management 2018, 8, 49-60, doi:10.1016/j.jdmm.2016.12.001.

24. Lourenço-Gomes, L.; Pinto, L.M.C.; Rebelo, J.F. Visitors' preferences for preserving the attributes of a world heritage site. Journal of Cultural Heritage 2014, 15, 64-67, doi:10.1016/j.culher.2013.01.003.

25. Gómez, M.S.; Almirón, A.; Bracco, M.G. La cultura como recurso turistico de las ciudades: el caso de la patrimonialización del tango en Buenos Aires, Argentina. Estudios y perspectivas en turismo 2011, 20, 1027-1046.

26. González Santa-Cruz, F.; López-Guzmán, T. Culture, tourism and world heritage sites. Tourism Management Perspectives 2017, 24, 111-116, doi:10.1016/tmp.2017.08.004.

27. del Barrio, M.J.; Devesa, M.; Herrero, L.C. Evaluating intangible cultural heritage: The case of cultural festivals. City, Culture and Society 2012, 3, 235-244, doi:10.1016/j.ccs.2012.09.002.

28. UNESCO. Safeguarding Intangible Heritage and Sustainable Cultural Tourism: Opportunities and Challenges; UNESCO: Bangkok, 2008.

29. Timothy, D.J.; Boyd, S.W. Heritage tourism; Pearson Education: 2003.

30. Timothy, D.J. Cultural heritage and tourism: An introduction; Channel View Publications: London, 2011.

31. Di Giovine, M.A. The heritage-scape: UNESCO, world heritage, and tourism; Lexington Books: 2008.

32. Park, H.Y. Heritage tourism; Routledge: 2014.

33. Timothy, D.J.; Boyd, S.W. Heritage tourism in the 21st century: Valued traditions and new perspectives. Journal of Heritage Tourism 2006, 1, 1-16, doi:10.1080/17438730608668462.

34. Su, M.M.; Wall, G. Chinese research on world heritage tourism. Asia Pacific Journal of Tourism Research 2011, 16, 75-88, doi:10.1080/10941665.2011.539392.

35. Trinh, T.T.; Ryan, C.; Cave, J. Evaluating heritage: tourists and holiday visits to heritage sites. Journal of tourism and Cultural Change 2016, 14, 129-149, doi:10.1080/14766825.2015.1032301.

36. Muñoz-Fernández, G.A.; López-Guzmán, T.; López Molina, D.; Pérez Gálvez, J.C. Heritage tourism in the Andes: the case of Cuenca, Ecuador. Anatolia 2018, 29, 326-336, doi:10.1080/13032917.2017.1408026.

37. Pérez-Priego, M.A.; García-Moreno, M.B.; Gomez-Casero, G.; del Río, L.C.L. Segmentation based on the gastronomic motivations of tourists: The case of the Costa Del Sol (Spain). Sustainability (Switzerland) 2019, 11, doi:10.3390/su11020409.

38. Saipradist, A.; Staiff, R. Crossing the cultural divide: Western visitors and interpretation at Ayutthaya World Heritage Site, Thailand. Journal of Heritage Tourism 2008, 2, 211-224, doi:10.2167/jht061.0.

39. Chen, G.; Huang, S. Understanding Chinese cultural tourists: Typology and profile. Journal of Travel E Tourism Marketing 2018, 35, 162-177, doi:10.1080/10548408.2017.1350253.

40. Silberberg, T. Cultural tourism and business opportunities for museums and heritage sites. Tourism Manage. 1995, 16, 361-365, doi:https://doi.org/10.1016/0261-5177(95)00039-Q. 
41. McKercher, B.; Du Cros, H. Testing a cultural tourism typology. International Journal of Tourism Research 2003, 5, 45-58, doi:10.1002/jtr.217.

42. Kelly, J.; Haider, W.; Williams, P.W.; Englund, K. Stated preferences of tourists for eco-efficient destination planning options. Tourism Manage. 2007, 28, 377-390.

43. Adie, B.A.; Hall, C.M.; Prayag, G. World Heritage as a placebo brand: a comparative analysis of three sites and marketing implications. Journal of Sustainable Tourism 2018, 26, 399-415, doi:10.1080/09669582.2017.1359277.

44. Huh, J.; Uysal, M.; McCleary, K. Cultural/heritage destinations: Tourist satisfaction and market segmentation. Journal of Hospitality E Leisure Marketing 2006, 14, 81-99, doi:10.1300/J150v14n03_07.

45. Bright, C.F.; Carter, P. Who are they? Visitors to Louisiana's River Road plantations. Journal of Heritage Tourism 2016, 11, 262-274, doi:10.1080/1743873X.2015.1100627.

46. Heung, V.C.; Quf, H. Hong Kong as a travel destination: An analysis of Japanese tourists' satisfaction levels, and the likelihood of them recommending Hong Kong to others. Journal of travel $\mathcal{E}$ tourism marketing 2000, 9, 57-80.

47. Truong, T.L.H.; Lenglet, F.; Mothe, C. Destination distinctiveness: Concept, measurement, and impact on tourist satisfaction. Journal of Destination Marketing and Management 2018, 8, 214-231, doi:10.1016/j.jdmm.2017.04.004.

48. Qu, H.; Kim, L.H.; Im, H.H. A model of destination branding: Integrating the concepts of the branding and destination image. Tourism Manage. 2011, 32, 465-476, doi:10.1016/j.tourman.2010.03.014.

49. Horng, J.-S.; Liu, C.-H.; Chou, H.-Y.; Tsai, C.-Y. Understanding the impact of culinary brand equity and destination familiarity on travel intentions. Tourism Manage. 2012, 33, 815-824, doi:10.1016/j.tourman.2011.09.004.

50. Kim, J.-H. The antecedents of memorable tourism experiences: The development of a scale to measure the destination attributes associated with memorable experiences. Tourism Manage. 2014, 44, 34-45, doi:10.1016/j.tourman.2014.02.007.

51. Chi, C.G.-Q.; Qu, H. Examining the structural relationships of destination image, tourist satisfaction and destination loyalty: An integrated approach. Tourism Manage. 2008, 29, 624-636, doi:10.1016/j.tourman.2007.06.007.

52. Meng, F.; Uysal, M. Effects of gender differences on perceptions of destination attributes, motivations, and travel values: An examination of a nature-based resort destination. Journal of Sustainable Tourism 2008, 16, 445-466, doi:10.2167/jost689.0.

53. Ozdemir, B.; Aksu, A.; Ehtiyar, R.; Çizel, B.; Çizel, R.B.; İçigen, E.T. Relationships among tourist profile, satisfaction and destination loyalty: Examining empirical evidences in Antalya region of Turkey. Journal of Hospitality Marketing \& Management 2012, 21, 506-540, doi:10.1080/19368623.2012.626749.

54. Yoon, Y.; Uysal, M. An examination of the effects of motivation and satisfaction on destination loyalty: a structural model. Tourism Manage. 2005, 26, 45-56, doi:10.1016/j.tourman.2003.08.016.

55. Chen, C.M.; Chen, S.H.; Lee, H.T.; Tsai, T.H. Exploring destination resources and competitiveness-A comparative analysis of tourists' perceptions and satisfaction toward an island of Taiwan. Ocean and Coastal Management 2016, 119, 58-67, doi:10.1016/j.ocecoaman.2015.09.013.

56. López-Guzmán, T.; Uribe Lotero, C.P.; Pérez Gálvez, J.C.; Ríos Rivera, I. Gastronomic festivals: attitude, motivation and satisfaction of the tourist. British Food Journal 2017, 119, 267-283, doi:10.1108/BFJ-06-2016-0246. 
57. Finn, M.; Walton, M.; Elliott-White, M. Tourism and leisure research methods: Data collection, analysis, and interpretation; Pearson education: 2000.

58. IMTUR. Observatorio Turístico. Availabe online: https://tinyurl.com/y4rq7v6b (accessed on August 4, 2020).

59. Kruskal, W.H.; Wallis, W.A. Use of ranks in one-criterion variance analysis. Journal of the American statistical Association 1952, 47, 583-621, doi:10.2307/2280779.

60. Mann, H.B.; Whitney, D.R. On a test of whether one of two random variables is stochastically larger than the other. The annals of mathematical statistics 1947, 50-60. 